\title{
Heder og ære til Torvid Kiserud
}

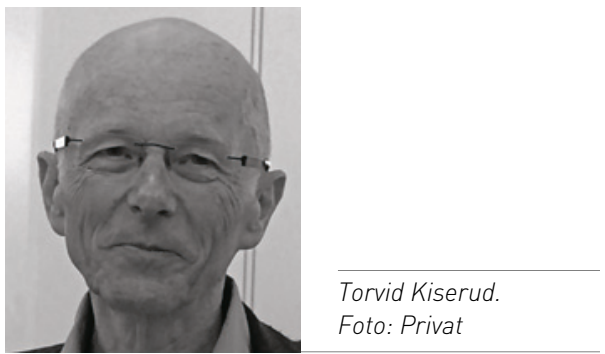

Torvid Kiserud (f. 1944), professor ved Klinisk institutt 2 ved Universitetet i Bergen, fikk i oktober 2015 overrakt Ian Donald Gold Medal. Medaljen ble delt ut på den 25. verdenskongressen for International Society of Ultrasound in Obstetrics and Gynecology (ISUOG), som fant sted i Montreal i Canada. Dette er den høyeste utmerkelse i dette fagfeltet.

Torvid Kiserud omtales gjerne som Mr. Ductus Venosus fordi han satte «fostershunten» på kartet, standardiserte ultralydmetoden, viste det fysiologiske grunnlaget og demonstrerte det store diagnostiske potensialet. Metoden er i daglig bruk verden over i forbindelse med morkakesvikt og fostersykdommer.
Kiserud har sammen med sine kolleger kartlagt fosterets sirkulasjon og vist hvilken viktig rolle fosterets leversirkulasjon har for vekst og utvikling. Forskerne har utdypet kunnskapen om fosterutviklingens betydning for helse og sykdom i senere faser av livet. Studiene har vært et samarbeid mellom Haukeland universitetssykehus og Universitetet i Bergen.

Gunn Marit Seberg

Tidsskriftet 